\title{
Urban Soils
}

\author{
Richard V. Pouyat, Susan D. Day, Sally Brown, \\ Kirsten Schwarz, Richard E. Shaw, Katalin Szlavecz, \\ Tara L. E. Trammell, and Ian D. Yesilonis
}

\section{Introduction}

The global population is expected to exceed 11 billion before the end of the twenty-first century (United Nations 2015). Populations within urban areas are also increasing, with the number of mega-sized (ten million people or more) cities expected to increase from 10 in 1990 to 41 in 2030 (United Nations 2015). In the United States, the human population is not growing as fast as the rest of the world, but the expansion of urban areas has proportionally kept pace, or exceeded, global estimates, with land devoted to urban uses growing by more than $34 \%$ between 1980 and 2000 alone (USDA NRCS 2001). Additionally, by 2010 almost 250 million people lived

R. V. Pouyat $(\bowtie)$

Northern Research Station, USDA Forest Service,

Newark, DE, USA

S. D. Day

Faculty of Forestry, University of British Columbia,

Vancouver, BC, Canada

S. Brown

School of Forest Resources, University of Washington,

Seattle, WA, USA

K. Schwarz

Departments of Urban Planning and Environmental Health

Sciences, University of California, Los Angeles,

Los Angeles, CA, USA

R. E. Shaw

U.S. Department of Agriculture, Natural Resources Conservation Service, New Jersey State Office, Somerset, NJ, USA

K. Szlavecz

Morton K. Blaustein Department of Earth and Planetary Sciences, Johns Hopkins University, Baltimore, MD, USA

T. L. E. Trammell

Department of Plant and Soil Sciences, University of Delaware, Newark, DE, USA

I. D. Yesilonis

U.S. Department of Agriculture, Forest Service, Northern Research Station, Baltimore Field Station, Baltimore, MD, USA in urban areas, which roughly accounts for $81 \%$ of the total population of the United States (U.S. Census 2010).

The relatively rapid expansion of urban areas in the United States, along with the juxtaposition of more than $80 \%$ of the population to the soils located in these areas, suggests the increasing national importance of "urban" soils. In this chapter we define and describe the role soil plays in urban landscapes and discuss the importance of these soils within the context of densely populated areas. Additionally, we provide an overview of what is known about the characteristics of urban soils and their role in the provisioning of ecosystem services. Finally, we assess the current state of knowledge of urban soils and provide a list of future informational needs.

\section{What Is an Urban Soil?}

The term "urban soil" was first used by Zemlyanitskiy (1963) to describe the characteristics of highly disturbed soils in urban areas. Urban soil was later defined by Craul (1992) as "a soil material having a nonagricultural, manmade surface layer more than $50 \mathrm{~cm}$ thick that has been produced by mixing, filling, or by contamination of land surface in urban and suburban areas." This definition was derived from, and is thus similar to, earlier definitions by Bockheim (1974) and Craul and Klein (1980). Since these earlier characterizations, Evans and others (2000) and later Capra and others (2015) use the term "anthropogenic soil," which places urban soils in a broader context of humanaltered soils rather than limiting the definition to densely populated urban and suburban areas alone. To recognize a broader set of observations, Effland and Pouyat (1997), Lehmann and Stahr (2007), and more recently Morel and others (2017) more broadly defined urban soils to include soils that are relatively undisturbed yet altered by urban environmental changes, such as the deposition of atmospheric pollutants. 


\section{A Range of Soil Conditions}

Soil conditions in urban areas generally correspond to a range of anthropogenic effects from relatively low influence (e.g., native forest or grassland soil) to those impacted by urban environmental effects such as patches of urban forest to soil types that are derived from human created materials, sealed by impervious surfaces, or altered by physical disturbances and management (Pouyat et al. 2009; Morel et al. 2017). The latter include massive or highly disturbed soils without structure (Short et al. 1986), human-transported materials (Shaw and Isleib 2017), sealed soils (Scalenghe and Marsan 2009), engineered soils such as green roof media and street tree pit soils (e.g., Grabosky et al. 2002), and soils that were once disturbed, but are now managed, such as public or residential lawns (Trammell et al. 2016). Therefore, comparisons among these soil uses should reflect the relative impact of urban effects such as site disturbances (site grading, use of sealed surfaces), subsequent management activities (fertilization, irrigation), intensity of use (trampling), plant cover, urban environmental changes (air pollution, habitat isolation) that are often novel, and site history (Pouyat et al. 2017; Burghardt 2017).

\section{Habitat for Soil Organisms}

Contrary to the generally held belief, urban soils are alive and may harbor a rich diversity of microorganisms and invertebrates. Urban soil communities are a unique combination of both native species that survive or thrive in the urban landscape and species that have been introduced from other regions or continents. Management practices also contribute to the uniqueness of urban soil communities. For instance, irrigation can overcome the lack of soil moisture as a serious site limitation for soil biota, and pesticides can eliminate nontarget species (Szlavecz et al. 2018). Soil sealing limits many soil organisms, although some taxonomic groups (e.g., earthworms [phylum Annelida] and ants [family Formicidae]) can survive under impervious surfaces or pavement (Youngsteadt et al. 2015). Landscaping practices, such as the removal of woody debris and leaf litter, deprive many species of shelter and food resources, while composting and mulching create new ones. In engineered soil environments such as green roofs and tree pit soils, entirely novel communities may assemble over time. The success of soil organisms in such circumstances depends on the constructed substrate, the connectivity among existing green roof habitats, and the age of the habitat (Burrow 2017; Madre et al. 2013).

\section{What Is the Role of Soil in Urban Ecosystems?}

Urban soils play multiple, and sometimes conflicting, roles within urban ecosystems (Setälä et al. 2014). Despite the high levels of disturbance typical of most urban soils, they, like their rural counterparts, have the potential to support plant, animal, and microbial organisms and to mediate hydrological and biogeochemical cycles (Pouyat et al. 2010). Each of these functions, however, must be evaluated specifically for urban conditions. Urban soil functions are often significantly altered from those of their rural counterparts, due not only to their modified characteristics but also because of their context within the urban landscape. As an example, consider a compacted soil that has been degraded by building construction or demolition. The permeability of this soil is impaired by compaction (a change in function), and its location in a mostly sealed environment results in the soil receiving much higher volumes of water via runoff (due to landscape position).

Soils play other critical functions that are unique to urban landscapes. For example, they provide a stable base for built structures such as buildings and roads. Additionally, urban soils provide physical support and a convenient and accessible location for underground utilities. They may serve roles in processing waste, whether from septic systems or from food and yard waste recycling programs. All soils have the capacity to accumulate various nutrients such as phosphorus $(\mathrm{P})$ and nitrogen $(\mathrm{N})$ that if transported to surface waters can cause environmentally damaging algal blooms. Soils also store significant levels of toxicants associated with urban environments (e.g., lead [Pb] and arsenic [As]), along with a host of macro and microartifacts (Rossiter 2007). These soils may endanger public health if humans subsequently come in contact with the soils when they are used for other purposes (e.g., urban agriculture or recreation).

\section{Importance of Soil in an Urban Context}

Soil provides vital and life-sustaining ecosystem services but is often underappreciated as a natural resource. This is particularly true for urban soils, which are assumed to be highly altered and thus not capable of providing the same ecosystem services as native, unaltered soils. However, as previously mentioned, urban soils can provide many of the same ecosystem services as nonurban soils (Morel et al. 2015; Pavao-Zuckerman 2012). In fact, in many cases the importance of these ecosystem services may actually be enhanced since they are, by definition, closely associated with high densities of people living in urban areas (e.g., Herrmann et al. 2017). In the following sections, we provide examples 
and present a conceptual framework for the provisioning of ecosystem services by urban soils.

\section{Juxtaposition of People and Soil: An Educational Opportunity}

Urban food production has provided a means to connect urban communities with urban soil systems. As an example, for over a decade, Growing Power in Milwaukee, WI, successfully used urban agriculture to build community involvement around food security, healthy food systems, and food justice. Programs, including youth engagement and training, showed how community food systems connect people and soil (Royte 2009). Another example is the Edible Schoolyard Project in Berkeley, CA, which has leveraged the process of growing food to teach school students not only about food production and preparation but also about soil ecosystems, ecological processes, and nutrition (https://edibleschoolyard. org/).

Although Growing Power and the Edible Schoolyard Project were pioneering projects, countless other urban agriculture endeavors have followed, and many have connected communities to valuable soil resources and educational opportunities (e.g., City Slicker Farms, Oakland, CA, and Detroit Black Community Food Network, Detroit, MI). These endeavors, however, are sometimes met with the challenges of legacy pollutants that can reduce or prevent realization of potential ecosystem services. An unfortunate example is the potential for $\mathrm{Pb}$ to be found in relatively high concentrations in urban agricultural and garden soils (Schwarz et al. 2012). Contamination of soil by $\mathrm{Pb}$, however, can be ameliorated through soil amendments that reduce the $\mathrm{Pb}$ bioavailability or, in more severe cases, through soil removal (Kumpiene et al. 2008). Community-level stewardship and investment by communities in the protection and improvement of soils to produce food in urban areas can be facilitated by network building and information exchange (Schwarz et al. 2016).

Community participation in urban soil stewardship relies on educational resources that allow people to gain a better understanding of the benefits of soils. Professional societies can play a role in providing these resources. For example, the Soil Science Society of America (SSSA) has developed a curriculum that addresses how humans have shaped soil systems and how people can work to protect soil (https://www. soils4teachers.org/). In addition to creating and overseeing K-12 curricula and hosting online seminars, the SSSA's year-long observance of the 2015 International Year of Soils was recognized for its innovation in communication. In New York City, NY, the Urban Soils Institute was created to provide soils information, testing, and education for green infrastructure, community gardening, urban agriculture, and restoration efforts (Fig. 7.1). Art has also been a creative means for communicating the value of soils. For example, the Hundred Dollar Bill Project, initiated by the nonprofit organization Fundred, is a collective art project with the goal of bringing awareness to the dangers of soil $\mathrm{Pb}$ and the importance of investing in a solution to improve both human health and soil (https://fundred.org/).

\section{An Ecosystem Services Framework for Urban Soils}

In the provision of ecosystem services, urban soil plays a unique role as the "brown infrastructure" of urban ecological systems, much in the same way urban vegetation is thought of as green infrastructure (Heidt and Neef 2008; Pouyat et al. 2007). While green infrastructure provides services attributed to vegetation, such as the moderation of energy fluxes by tree canopies (Akbari 2002; Heidt and Neef 2008), brown infrastructure provides ecosystem services attributed to soil, such as those previously mentioned.

Traditional engineering approaches, especially those used in urban areas, typically address ecosystem service deficits with built or gray infrastructure or, alternatively, may actually move the ecosystem service function off-site. An example is the collection of wastes from urban areas through a sewer system of pipes to a sanitary treatment plant (i.e., gray infrastructure). Subsequently, processed sanitary wastes may be transported to rural areas and applied as a soil amendment, effectively recycling wastes using soil processes; but transporting wastes off-site can result in the emissions of greenhouse gases from the vehicles transferring the waste. More innovative engineering approaches, however, utilize the recycling function of urban soils within the urban ecosystem rather than creating emissions by transporting the waste to a rural area. Stormwater management is another soil function traditionally addressed by gray infrastructure. Urban soil, however, can be utilized as a permeable media to reduce runoff (e.g., rain gardens) and as such works with green and gray infrastructure to reduce stormwater overflow (Kaushal and Belt 2012).

These newer and more innovative roles for urban soils create new opportunities for realizing ecosystem services and for conceptually framing how we consider these services and the disciplinary and management approaches we implement to enhance them (Fig. 7.2). Provisioning services include traditional services such as food production but also include novel services such as those that support structures and roads. Regulating services include storage of soil $\mathrm{C}$ and mitigation of greenhouse gas emissions and novel services such as stormwater retention and waste management. Supporting services include soil formation and nutrient cycling but also may include the sequestration of contami- 


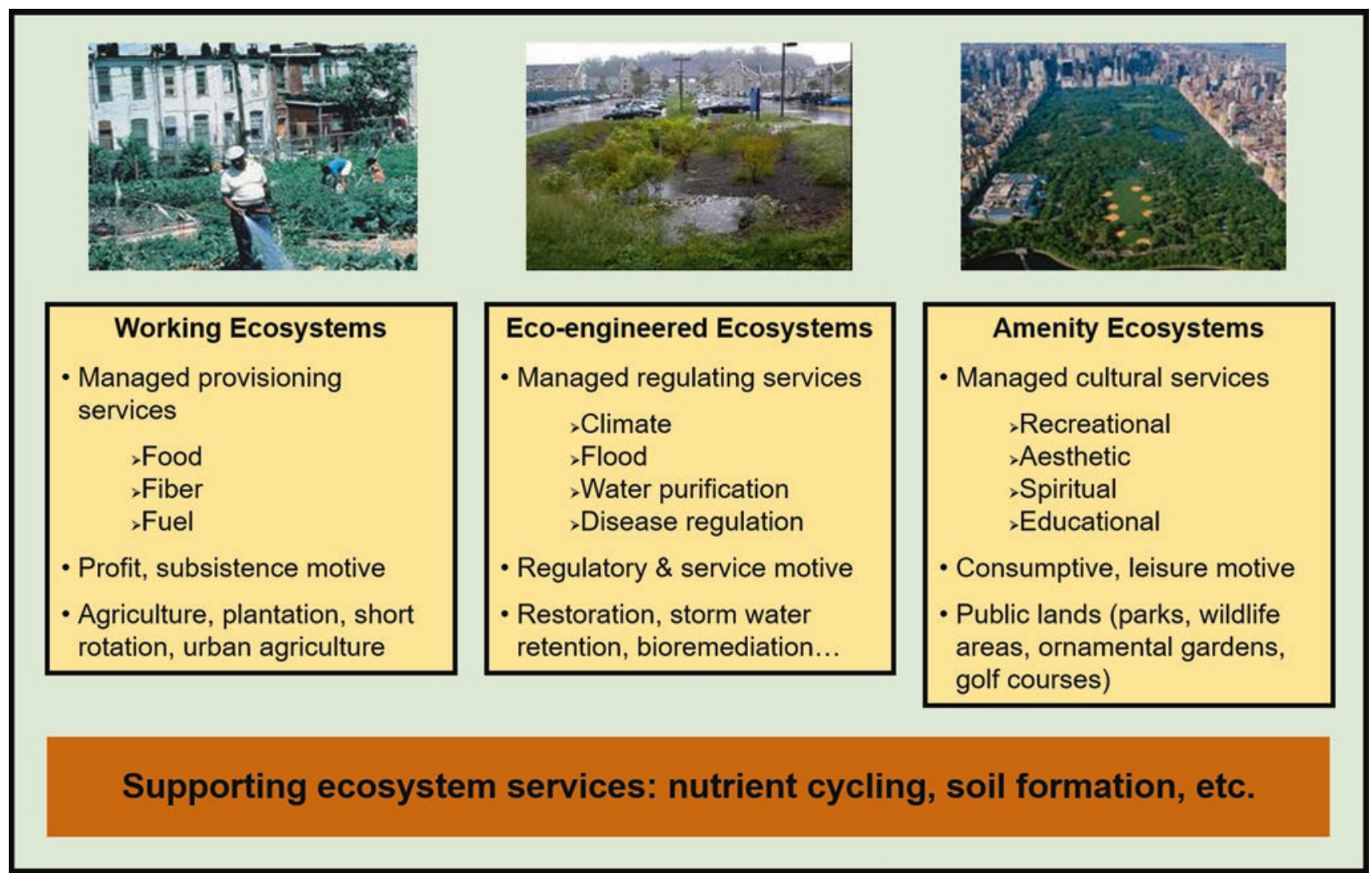

Fig. 7.1 As with nonurban soils, urban soils provide ecosystem services. Because of the close proximity of urban soils with dense human populations, the importance of ecosystem services is especially magnified for managed regulating services and managed cultural services

Fig. 7.2 Soils training session for environmental stewardship conducted by the USDA Natural Resources Conservation Service and the New York City Urban Soils Institute, Bronx, NY. (Photo credit: Richard Shaw, USDA Natural Resources Conservation Service)

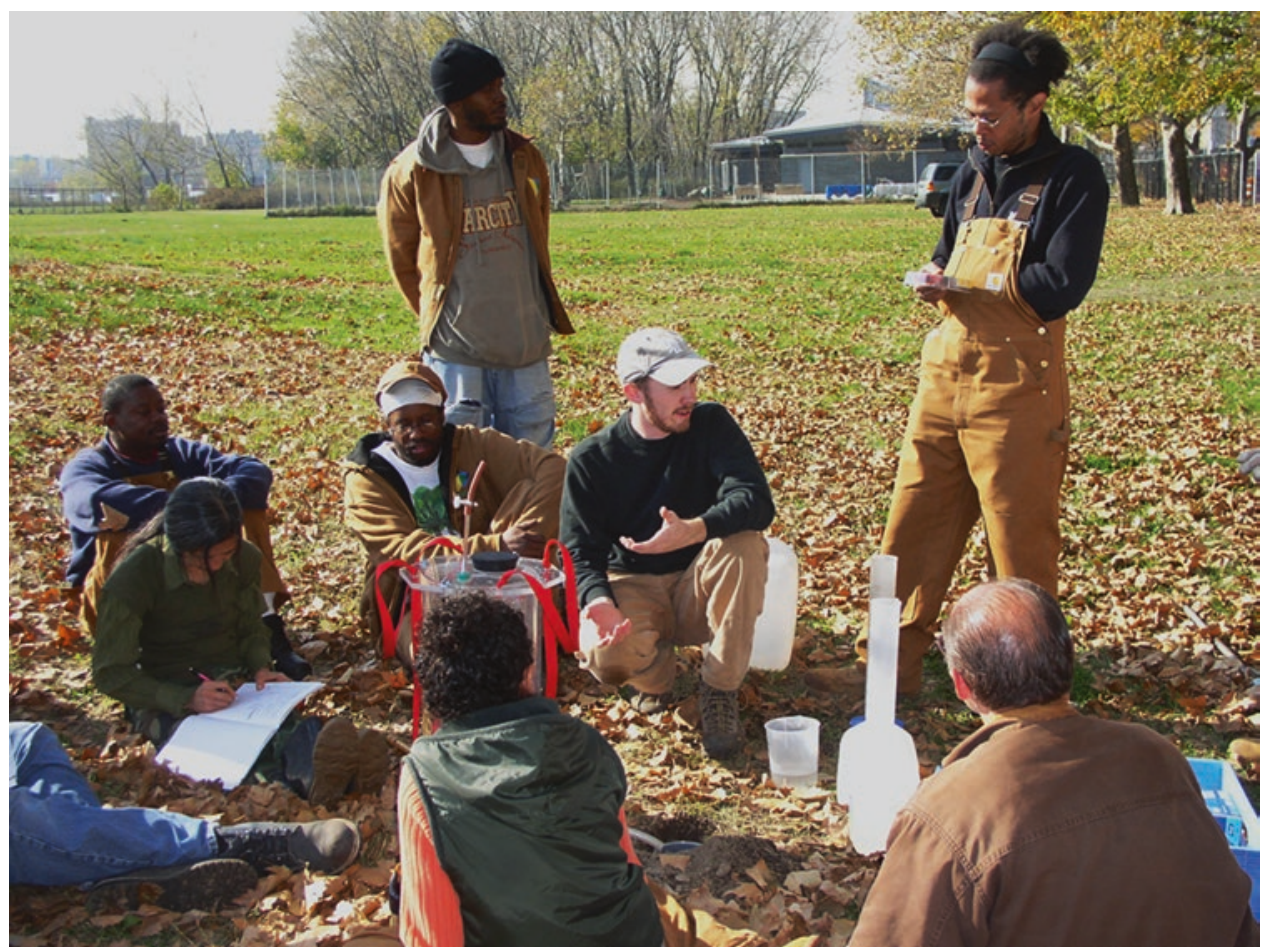


nants to reduce human exposure and improve public health. Finally, cultural services, which include the support of public greenspaces used for recreation, aesthetic, or spiritual values, will be enhanced in urban areas because of the high level of human access. Each of the ecosystem services provided by urban soils can be modified by soil management practices and may also be integrated with engineered approaches (Morel et al. 2015).

\section{Anthropogenic Influences on Urban Soils and Their Assessment}

As land is converted to urban uses, soil scientists consider both direct and indirect factors that can affect soil characteristics. Direct effects include those typically associated with urban soils, such as physical disturbances, incorporation of humancreated materials, and burial or coverage of soil by fill material and impervious surfaces. Indirect effects are less noticeable and involve changes in the abiotic and biotic environment, which can even affect undisturbed soils within urban and periurban or suburban areas (Pouyat et al. 2010). The resultant conditions of both direct and indirect effects embody what ecologists and soil scientists refer to as "novel" ecosystems (Hobbs et al. 2006). These novel ecosystems represent the suite of conditions that have created and formed urban soils over time since humans began congregating and living in densely populated settlements or cities more than 5000 years ago.

\section{Direct Effects}

Urbanization is characterized by the built environment- - the buildings, roads, and other structures that form the communities where humans live and work - and subsequent human activity in that environment. The conversion of forested and agricultural lands to urban uses often results in a host of rapid changes related to land development and grading. As humans live and work in this environment, they manipulate soils for a wide variety of purposes, which range from stormwater management, lawn maintenance, and landscaping to urban agriculture and recreation. Furthermore, human activity generates waste products, including everything from industrial waste to feces of pets.

\section{Land Use Change and Urbanization}

Land development associated with land use change and urbanization occurs not only at the perimeters of urban areas but also in periurban or suburban communities and in the interior of cities through infill development (Setälä et al. 2014). Usually the first phase of development is to create level topography through grading. During this process, the landscape is altered by the removal of surface O- and
A-horizon soils, and the remaining soils are compacted from the use of heavy equipment. Even if surface soils are replaced after construction, soil structure is degraded, considerable soil carbon (C) stocks are lost (e.g., Chen et al. 2013), and hydraulic conductivity is greatly reduced (e.g., Schwartz and Smith 2016). Additionally, lower soil horizons may be severely compacted, especially if grade changes are significant or soils are located in construction staging areas.

\section{Waste Disposal}

Dense populations and concentrated activity in urban areas generate a significant amount of waste products. Domestic and industrial waste materials, construction debris, ash from heat and power production, and dredge spoils commonly end up as components of urban soils. In many areas, these materials have been used to fill wetlands or extend the shoreline, but most cities have now created domestic landfills to address part of the waste problem. Many of these human-made or processed artifacts, which can include black $\mathrm{C}$, trace metals, and organic contaminants, have properties that are unlike natural soils, and these materials can have profound effects on soil-forming processes and soil properties (Huot et al. 2015).

\section{Grading and Stormwater Management}

Soil and its management can be a useful tool in retaining stormwater during and after the land development process (Shuster et al. 2014; Shuster and Dadio 2017). As an example, grading is used to alter water flow paths to direct overland flow into soil-plant reservoirs such as with bioretention cells and rain gardens. These reservoirs are often filled with engineered "bioretention" soil mixes that allow for rapid infiltration and are highly penetrable by roots (Kaushal and Belt 2012). Additionally, various techniques such as deep ripping followed by compost amendment can significantly increase permeability in soils degraded by compaction (Chen et al. 2014; Schwartz and Smith 2016).

\section{Sealing and Paving}

A high proportion of urban land is covered by impervious surfaces, with much of this surface being soil sealed by asphalt or concrete pavement (Scalenghe and Marsan 2009). Few studies of soils beneath pavement have been conducted. Paving or sealing the soil surface interrupts the flow of energy and materials (including detritus) and, therefore, is disadvantageous to the provision of most ecosystem services. As a consequence, the water and nutrient cycles are disrupted, the heat balance is altered, more anoxic conditions prevail, and thus habitat for root growth and many soil organisms is lost. Existing research indicates that $\mathrm{C}$ and $\mathrm{N}$ contents are lower in sealed areas than in adjacent unsealed soils (Table 7.1) (Piotrowska-Dlugosz and Charzynski 2015; Raciti et al. 2012). 
Table 7.1 Soil organic carbon stocks to $1 \mathrm{~m}$ for soil types in two different cities

\begin{tabular}{l|c|l|r|l}
\hline Soil type & $\mathrm{C}\left(\mathrm{kg} \mathrm{m}^{-2}\right)$ & Land area $(\%)$ & Hectares & Total C $(\mathrm{Mg})$ \\
\hline New York, $N Y$ & \multicolumn{5}{|l}{} \\
\hline Natural $^{\mathrm{a}}$ & 22.2 & 6.8 & 5256 & $1,362,080$ \\
\hline HAHT $^{\mathrm{b}}$ & 18.3 & 25.4 & 19,626 & $3,428,416$ \\
\hline Sealed soils & 6.0 & 62.6 & 48,328 & $2,885,155$ \\
\hline Baltimore, $M D^{\mathrm{c}}$ & \multicolumn{5}{|l}{} \\
\hline Natural & 10.2 & 38.2 & 7995 & 815,490 \\
\hline HAHT & NA & 19.2 & 4021 & NA \\
\hline Sealed soils & 3.3 & 42.6 & 8898 & 293,634
\end{tabular}

aNatural soils include brown till, red till, tidal marsh, and outwash ${ }^{\mathrm{b}} \mathrm{HAHT}$ are human-altered or human-transported soils that include spolic, artifactual, dredgic, and combustic soils

'Data from Yesilonis and Pouyat (2012); natural soils do not include wetlands

Due to the high proportion of sealed surfaces in urban areas, more burden is exerted on the fragmented unsealed areas to provide provisioning, regulating, and supporting services (Setälä et al. 2014). Because cities are often situated in areas with few site limitations (e.g., level topography and well-drained soils), many of the most productive agricultural soils end up sealed and disturbed as urban areas expand (Wessolek 2008). The few advantages of soil sealing include rapid removal of stormwater runoff, containment of pollutants, and the preservation of cultural heritage (e.g., the ruins of Pompeii) (Scalenghe and Marsan 2009; Wessolek 2008).

An indirect effect of concrete surfaces is the introduction of secondary or pedogenic carbonates, which are commonly found in many urban soils as a result of the weathering of calcium silicate and hydroxide minerals from concrete (Washbourne et al. 2015). Dust additions and natural parent materials can also supply calcium carbonate, which can lead to a relatively high soil $\mathrm{pH}$ that provides buffering against soil acidification (Pouyat et al. 2007).

\section{Soil Replacement and Recycling}

Infill development may occur where soils are absent (e.g., displaced by underground structures), severely degraded (e.g., were previously beneath structures or roadways and are compacted and contain a variety of artifacts), or capped because of the accumulation of contaminants. In these cases, soil is often imported from soil blending or recycling facilities. At such facilities, soil is typically screened and blended with sand and compost. The resulting blended soils are sometimes more susceptible to compaction, are poorly structured, and have a lack of aggregate formation; therefore they may have lower water holding capacities than the soils they replace (e.g., Spoor et al. 2003).

\section{Lawn Management}

The estimated amount of lawn cover for the conterminous United States is $163,800 \mathrm{~km}^{2} \pm 35,850 \mathrm{~km}^{2}$, which accounts for almost three-quarters of all irrigated cultivated lands (Milesi et al. 2005). To manage turf grass cover, almost half of all residences apply fertilizers (Law et al. 2004; Osmond and Hardy 2004), with some applying fertilizer rates similar to or exceeding those of cropland systems (e.g., $>200 \mathrm{~kg} \mathrm{ha}^{-1}$ year $^{-1}$ ) (e.g., Morton et al. 1988). While the potential for losses of $\mathrm{C}$ and $\mathrm{N}$ in residential areas can be high (Byrne et al. 2008), turf grass systems have shown the capacity to retain a surprising amount of $\mathrm{C}$ and $\mathrm{N}$ when compared to agricultural soils (Scharenbroch et al. 2018; Trammell et al. 2016). This apparent retention may be due to turf grass management efforts (e.g., irrigation) that maintain high plant productivity, which can lead to organic matter accumulation in soil (Groffman et al. 2009; Pouyat et al. 2002).

\section{Indirect Effects}

Humans indirectly influence urban soil conditions through activities that alter urban climatic conditions (e.g., temperature and moisture), chemical inputs (e.g., pollutant and nutrient concentrations), and spread of native and nonnative invasive species (Pouyat et al. 2010). Cities are warmer due to increased heat-generating activities and reduced heat losses because of less evaporative cooling surface (Taha 1997; Zhao et al. 2014), a phenomenon called the "urban heat island" (Oke 1990). Elevated atmospheric deposition of nutrients (Lovett et al. 2000; Rao et al. 2014) and other pollutant inputs, such as ozone $\left(\mathrm{O}_{3}\right)$, can indirectly alter the chemical composition of organic matter (OM) inputs to soil as well as the microbial activity. The addition of nonnative species in urban landscapes (McKinney 2006) also affects soil conditions and biogeochemical cycles (Ehrenfeld 2010; Liao et al. 2008). Introduced invasive plants, soil organisms, and plant insect pests alter plant composition and subsequent plant chemical inputs to soil, in turn altering soil microbial community structure and activity. These indirect human influences on soils alter both soil structure (e.g., aggregate formation) and function (e.g., $\mathrm{N}$ cycling).

\section{Urban Climate}

The urban heat island is linked with changes in plant phenology, including timing and duration of canopy leaf out, leaf budburst, and flowering (Chen et al. 2016; Jochner and Menzel 2015). The urban heat island effect varies by species (Xu et al. 2016) and alters the timing and quantity of OM inputs to the soil environment. Results from experimental soil warming studies suggest that soil microbial activity and soil ecosystem processes in urban landscapes may be accelerated due to the urban heat island effect (Butler et al. 2012; Craine et al. 2010). However, the net effect of soil warming on microbial processes and biogeochemical cycles (e.g., net soil $\mathrm{CO}_{2}$ flux) will 
depend on potential compensation from other anthropogenic factors that may restrict microbial activity in urban ecosystems. While the urban heat island effect in cities has been well studied, the alteration of precipitation in cities is complex and is now a focus for atmospheric scientific research (Shepherd and Burian 2003; Song et al. 2016). Numerous studies have identified an "urban rainfall effect" (Shem and Shepherd 2009; Shepherd and Burian 2003), where urban areas experience increased rainfall, snowfall, and convection storm events compared to nearby rural areas (Niyogi et al. 2011; Shem and Shepherd 2009; Taha 1997). The combined effect of altered temperature and precipitation regimes in urban environments can affect plant productivity, and thus, the quantity and quality of OM inputs to the soil, and microbial activity, all of which strongly influence urban soil structure and function.

\section{Urban Atmospheric Chemistry}

Human activities in urban areas alter the chemical environment of soils by elevating nutrients (e.g., $\mathrm{N}$ deposited from the atmosphere) and increasing atmospheric pollutant concentrations (e.g., $\mathrm{O}_{3}$ ), which can strongly influence the chemical composition and the quantity of organic matter inputs to the soil. Urban precipitation contains greater concentrations of inorganic $\mathrm{N}$, calcium $(\mathrm{Ca})$, and magnesium $(\mathrm{Mg})$ that may actually have beneficial effects on plants and microbes via increased nutrient availability; however, the increase in hydrogen ions (acidity) in precipitation may be detrimental for many soil-swelling organisms (Carreiro et al. 2009; Lovett et al. 2000). Urban environments also have elevated $\mathrm{CO}_{2}$, nitrogen oxides $\left(\mathrm{NO}_{\mathrm{x}}\right), \mathrm{O}_{3}$, and other air pollutants in the atmosphere. How altered chemical inputs affect plant growth, and in turn soil processes, in urban areas is not fully understood (Calfapietra et al. 2015). For example, plant productivity may be stimulated by $\mathrm{N}$ deposition and elevated $\mathrm{CO}_{2}$ yet dampened by greater $\mathrm{O}_{3}$ concentrations (Gregg et al. 2003). Soil N cycling rates in urban environments may increase due to increased $\mathrm{N}$ availability (Pardo et al. 2011) or decrease due to the production of more complex phenolic compounds by stressed plants or depressed enzyme activity by fungi, which are important in the decay of organic matter (Carreiro et al. 2000; Findlay et al. 1996). Therefore, the cumulative effects of altered atmospheric deposition as well as ozone have the potential to stimulate or depress soil organic matter and nutrient pools over time.

\section{Nonnative and Invasive Species}

Species invasion is a global phenomenon that causes ecological and economic damage to soil ecosystems including those situated in urban areas (Szlavecz et al. 2018). Urban areas are often the epicenter for nonnative species introductions because cities are transportation hubs supporting global commerce and international trade (McKinney 2006). Nonnative invasive species commonly found in urban envi- ronments, such as nonnative invasive plants, nonnative earthworms (suborder Lumbricina), and nonnative tree pests, can have significant impacts on soil conditions (e.g., $\mathrm{pH}$ ) and processes (e.g., N cycling) (Ehrenfeld 2010).

Species introduction of soil invertebrates is usually accidental and happens through transportation of plants or soil. Historically, soil was used as ballast material in ships bound for North America, and many species from the Atlantic and Mediterranean regions crossed the oceanic barrier in this way (Lindroth 1957). Species that generally do well in human-dominated environments were successful. Many common earthworms, terrestrial isopods (order Isopoda), millipedes (family Diplopoda), snails (class Gastropoda), and beetles (order Coleoptera) dominating urban soils in North America are from other biogeographical realms. Greenhouses provide a shelter and "jumping board" for species arriving from different climatic regions. Some species, such as silverfish (Lepisma saccharina) and cave crickets (order Orthoptera, family Rhaphidophoridae), remain in close proximity to humans, while others escape and spread through the landscape (Garthwaite et al. 1995). At the same time, remnant patches of natural vegetation can serve as refugia for populations of native invertebrates (Korsós et al. 2002). The dominance of nonnative species over natives is taxon dependent. For instance in the Northeast region, carrion beetles (order Coleoptera, family Silphidae) are native, and their community composition is driven by urban forest patch size and quality, while woodlice (order Isopoda) assemblages are entirely made up of introduced species (Hornung and Szlavecz 2003; Wolf and Gibbs 2004).

Nonnative invasive plants exert pressure on ecosystems by altering plant community composition, plant productivity and phenology, litter decomposition, and soil processes (Jo et al. 2015; Liao et al. 2008; Trammell et al. 2012). Furthermore, invasions by nonnative plants can shift microbial community composition (Arthur et al. 2012; Kourtev et al. 2003) and have cascading effects on belowground nutrient cycles. Similarly, nonnative earthworms alter soil structure and biogeochemical cycles (Szlavecz et al. 2011) and in urban forests were shown to enhance $\mathrm{N}$ cycling and leaf litter decay rates (Pouyat and Carreiro 2003; Szlavecz et al. 2006). Hence, greater earthworm abundance in urban soils may be associated with lower soil OM (Sackett et al. 2013; Smetak et al. 2007) and altered microbial composition (Drouin et al. 2016; Scharenbroch and Johnston 2011). While nonnative plants and earthworms directly interact with urban soils, nonnative insect pests can devastate native tree populations in cities, significantly reducing the urban tree canopy, as is the case with emerald ash borer (Agrilus planipennis) (Poland and McCullough 2006). This reduction in urban tree foliage can decrease OM inputs to soil; however, how nonnative insect pests influence urban soil conditions or processes is not well understood. 


\section{Mapping, Classification, and Interpretation}

The past decade has seen an increase in urban soil survey efforts in the United States. Modern soil surveys for New York City, Chicago, IL, Los Angeles, CA, and Detroit now provide detailed information on physical, chemical, and mineralogical properties of human-altered and humantransported soils, enabling more reliable ratings and interpretations for stormwater management, revegetation and restoration efforts, urban agriculture, and better resource inventory. Maps derived from digital elevation models (DEMs) and digitized surface geology along with greater access to engineering logs and reports assist in identifying and understanding anthropogenic alteration and eventually making some predictions about soils and landscapes (Fig. 7.3). In the field, geophysical, nondestructive methods are increasingly being used to characterize spatial variability of soil properties in urban areas. Ground-penetrating radar can identify contrasting materials, discontinuities, and subsurface interfaces (Doolittle et al. 1997). Electromagnetic inductance and magnetic susceptibility can distinguish certain types of artifactual material (Howard and Orlicki 2015). Portable X-ray fluorescence spectrometry can be used to detect and map concentrations of $\mathrm{Pb}$ and other trace metals in the soil (Carr et al. 2007).

Cooperation with universities and Federal, state, and municipal agencies helps to address local soil issues and survey needs, provide operational guidance, and offer opportunities for outreach and education. Although there are global similarities in soil characteristics, the urban soil pattern is unique for every city and is affected by history, geology, and geography. For instance, European settlement in New York City began in 1609 in an area with three islands and one peninsula (772 $\mathrm{km}^{2}$ total) and limited room for expansion. It was accompanied by extensive filling of wetlands and expansion of the shoreline, much of which was done with waste materials such as construction debris and dredge spoils (Fig. 7.4a). Consequently most of the city's soils are human-altered or human-transported (HAHT), many with a considerable artifact content. In contrast, much of the growth and expansion of Los Angeles took place after 1870 , and the city had sufficient room to expand (from $73 \mathrm{~km}^{2}$ to $233 \mathrm{~km}^{2}$ to $1215 \mathrm{~km}^{2}$ ). The predominant form of human disturbance in Los Angeles was land leveling and terracing, much of which involved a relatively small depth $(<50 \mathrm{~cm})$ of surface alteration (Fig. 7.4b). As a result, Los Angeles has a lower percentage of sealed surfaces and HAHT soils (Table 7.2).

There have also been recent updates in the classification of urban soils. The World Reference Base for Soil Resources, an international correlation system, added a Technosols reference soil group for soils dominated by technic or artifactual materials (Rossiter 2007). The USDA Soil Taxonomy added definitions of anthropogenic landforms and microfeatures, artifacts, and HAHT materials, along with 12 HAHT family classes (Soil Survey Staff 2014). Both systems are open to revision and likely to change with advances in urban soil research and mapping.

In an alternative approach, Morel and others (2015) proposed a categorization of soils in urban areas according to their capacity to deliver various ecosystem services (provi-
Fig. 7.3 LiDAR (light detection and ranging)derived digital elevation models (DEMs) use pulsed laser light to measure distances. This highresolution topographical information can be used for urban soil surveys. (Image by Randy Riddle, USDA Natural Resources Conservation Service)

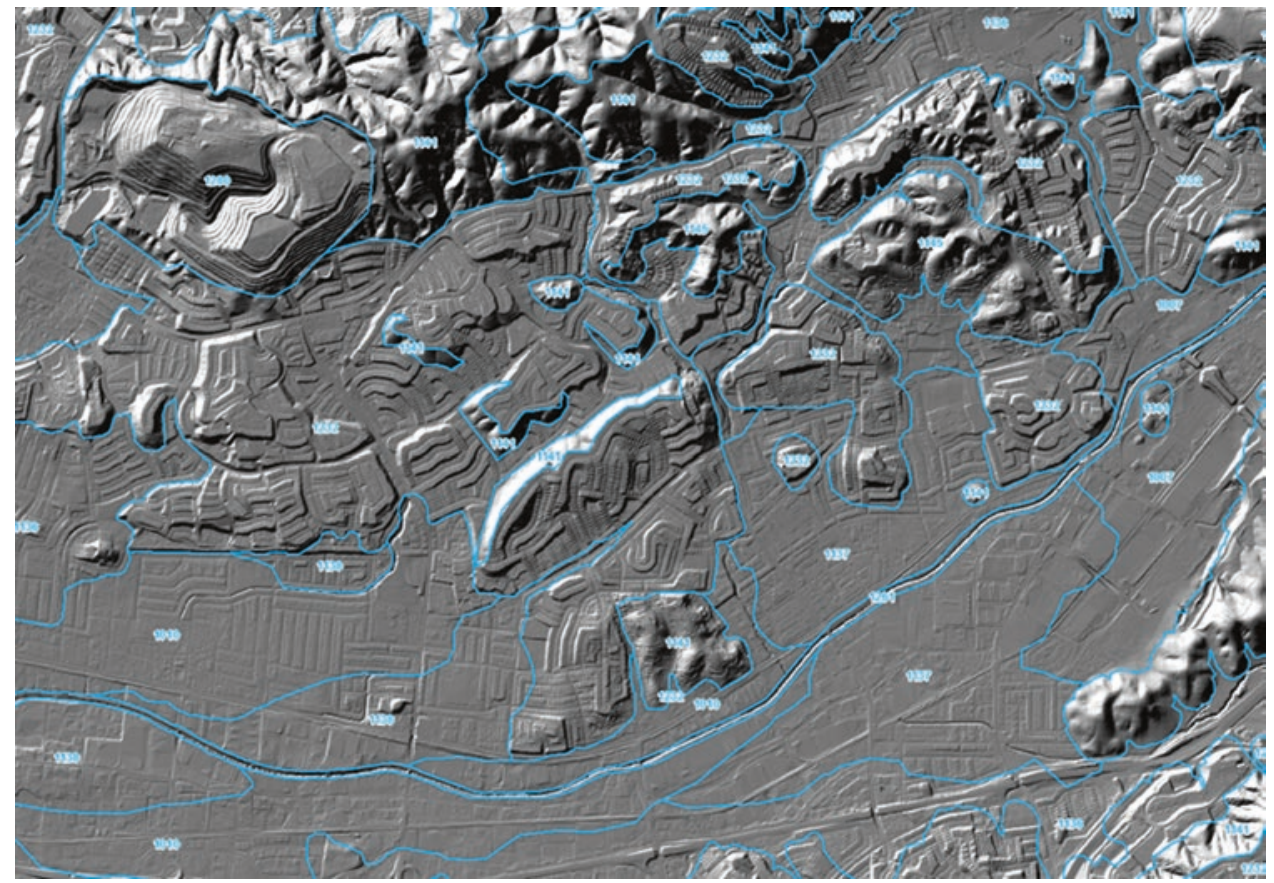


a.

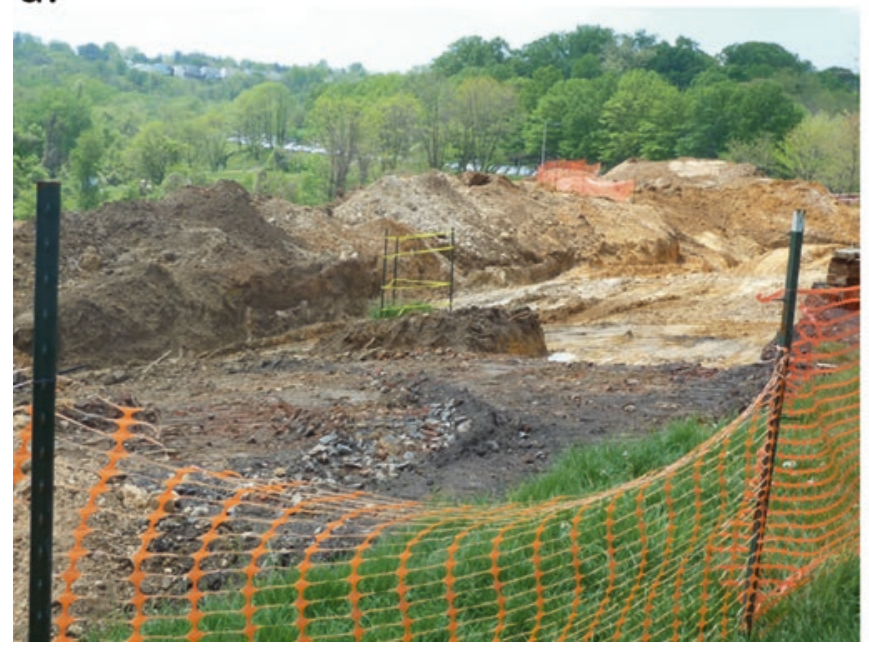

Fig. 7.4 Extensive filling of wetlands and expansion of shorelines often accompanies the development of urban areas. (a) Frequently, the fill material is made up of waste materials such as construction debris and dredge spoils. (b) In steep topography, the predominant form of

Table 7.2 Soil/land cover type comparison, New York and Los Angeles

\begin{tabular}{l|l|l|l|l}
\hline & \multicolumn{4}{|l}{ Percentage of land area } \\
\hline City & Sealed soil & HAHT $^{\mathrm{a}}$ soils & Natural soils & Non-soil \\
\hline New York, NY & 63 & 27 & 9 & 1 \\
\hline Los Angeles, & 43 & 11 & 44 & 2 \\
CA & & & & \\
\hline
\end{tabular}

${ }^{a}$ HAHT are human-altered or human-transported soils that include spolic, artifactual, dredgic, and combustic soils

bNatural soils include brown till, red till, tidal marsh, and outwash

sioning, regulating, cultural). The classification was based on a gradient of anthropogenic disturbance and the capacity of the soils to support vegetation. The main objective was to improve the recognition of ecosystem service provision and offer new insight on soil management, design, and engineering in the urban environment.

Ecosystem service delivery can also vary with usedependent or dynamic soil properties such as soil organic matter, soil structure, bulk density and porosity, $\mathrm{pH}$, electrical conductivity, and nutrient availability. Land use and cover are not regularly differentiated in the soil survey, but for the recent USDA NRCS Soil Survey of New York City, land use-dependent map units were designed in order to assign more precise data on soil physical, chemical, and mineralogical properties. Such data will allow for more reliable interpretations and ratings for green infrastructure, urban agriculture, landscape architecture, and land use classifications, as well as assessment of ecosystem service delivery potential. b.

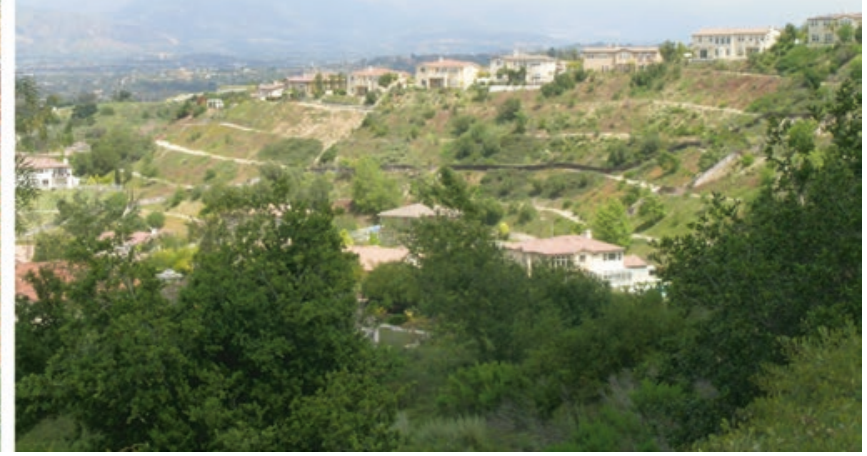

disturbance is often land leveling and terracing, which involves altering a relatively small amount $(<50 \mathrm{~cm})$ of the surface. (Photo by Randy Riddle, USDA Natural Resources Conservation Service)

\section{Opportunities for Ecosystem Service Enhancements in Cities}

As mentioned previously, urban soils can provide many benefits, including $\mathrm{C}$ sequestration, reduced stormwater runoff, improved water quality, food production, and recreation. Not all of these outcomes, however, are aligned with one another and in some cases may even conflict. Thus, managing soil in urban areas for ecosystem services requires an interdisciplinary approach. As an example, soil scientists, ecologists, engineers, and horticulturists are actively engaged in assessing and improving the performance of bioinfiltration soil mixes for both pollutant removal and plant growth (for review, see Roy-Poirier et al. 2010). Landscape architects may engage in soil management through specifying custom blended soil mixes for various types of vegetation (Craul 1992). Urban foresters may employ engineered soils to address conflicting soil functions such as supporting pavement while allowing tree root growth (Sloan et al. 2012). As the many benefits of soils are better understood and urban design becomes more multifunctional, the engagement of diverse disciplines in soils research and practice can be expected to expand. There are a number of examples in which scientists, practitioners, and residents have worked together to address the enhancement of ecosystem services provided by urban soils, including the recycling of municipal waste as a soil amendment, engineered soils associated with green roofs and street pits, and the use of plants to maintain or restore the diversity of organisms inhabiting the soil. Here we provide a few examples. 


\section{Recycling Municipal Waste to Enhance Urban Soils}

Every municipality is charged with handling waste materials that can be used to enhance soils and associated ecosystem functions. Examples of these materials include the organic component of municipal solid waste and the liquid and solid residuals from wastewater treatment. Soils themselves can also be waste materials from construction and dredging projects and road maintenance operations. However, departments within a municipal infrastructure charged with handling wastes and those that could potentially use these same materials are often segregated, with minimal incentive to find common purpose. Even when overlapping interests are found within a single division, there is often no recognition or action based on this overlap. Benefits can be optimized by identifying appropriate end uses for soil-building material and optimizing those uses within the municipal infrastructure, but this requires interdepartmental cooperation and may also involve nontraditional stakeholders. One example of this is the Harvest Pierce County program in Tacoma and Pierce Counties in Washington, a program that manages approximately 80 community gardens and a farm that utilize biosolids and compost as soil amendments (Box 7.1).

\section{Soil Amendments to Reduce Contaminant Bioavailability}

Although soils can provide many ecosystem services, soil contaminants can be harmful. Soils can serve as a sink for legacy pollution and are a potential source of exposure to human populations if ingested or inhaled (Schwarz et al. 2012). In some cases, especially in postindustrial urban areas, pollution is widespread, making the removal and disposal of soil impractical (Farfel et al. 2005). As an alternative, researchers have looked at the role that amendments may play in mitigating potential risk to human populations (Kumpiene et al. 2008). In the case of metal(loid)s, amendments can be used to either immobilize or mobilize pollutants by changing the bioavailability of the contaminant (Bolan et al. 2014). For example, chelating agents can be used to mobilize heavy metal(loid) s to encourage plant uptake (Bolan et al. 2014). More commonly, amendments are used to immobilize contaminants to reduce uptake by biological systems. The addition of phosphorus-containing amendments or fertilizers has been of great interest due to their capacity to form pyromorphite, which demonstrates low solubility (Kumpiene et al. 2008; Ryan et al. 2001). The addition of organic matter via compost or biosolids may also tightly bind $\mathrm{Pb}$, making it less bioavailable (Farfel et al. 2005). In addition to changing the bioavailability of pollutants, amendments may also address potential exposure by (1) diluting the concentration of pollutants in the soil and (2) promoting the growth of vegetation, which can serve as a protective barrier between contaminated soil and people. Managing soil contaminants through the use of amendments has the potential to enhance the ecosystem service of pollutant retention and restore land uses such as recreation and food production (Schwarz et al. 2016). However, unlike soil removal, the process can be slow and dynamic, making sustained maintenance and monitoring a necessity.

\section{Green Roofs: An Opportunity for Ecosystem Service Enhancement}

Soils for green roofs are typically engineered substrates designed to be lightweight while still supporting plant life, although natural mineral soils are used in some instances, especially for rooftop farming (e.g., Brooklyn Grange, https://www.brooklyngrangefarm.com). Green roofs provide multiple opportunities for ecosystem service enhancement via soils. Roofs cover $20-25 \%$ of some cities (Akbari and Rose 2008) and offer a significant area for new soils to provide ecosystem services and habitat for plants and other biota. Soils and plants on green roofs can mitigate large amounts of stormwater, although green roofs in general cost more than other stormwater controls. They may also be a source for nutrient or pollutant export if green roof soil-plant systems are not carefully designed (Seidl et al. 2013). Furthermore, because green roof soils often require very specific physical properties while maintaining a relatively low density, they have been created from a variety of recycled materials, including roof tiles (Emilsson and Rolf 2005), bricks, glass, and paper pellets (Molineux et al. 2009). Therefore, green roof soils often require nutrient supplements, making them an avenue for utilizing urban waste products. Engineered green roof soils may accumulate a substantial amount of organic matter over time (Schrader and Böning 2006), but soil formation processes in these soils are poorly understood. Green roofs are an example of creation and evolution of novel assemblages of soil organisms. Microbes and invertebrates colonize these spaces and create unique communities over time. Additionally, the variety of green roof designs provides an excellent opportunity to investigate how habitat structure can affect biodiversity (Madre et al. 2013; McGuire et al. 2013). In several instances, arthropod diversity has been shown to be high and include rare species (Kadas 2006; MacIvor and Lundholm 2011).

\section{Diverse Plant Communities Stabilize Ecosystem Service Enhancement}

A long-term ecological paradigm is that increased biodiversity enhances ecosystem productivity and stability. Although there is debate about the mechanisms by which diversity influences ecosystem stability, foundational experiments have shown that biodiversity is an important determinant of temporal stability, consumption of limiting resources, and 


\section{Box 7.1 Harvest Pierce County Program}

The Harvest Pierce County program in Tacoma and Pierce County in Washington manages community gardens and a gleaning program that now serves approximately $80 \mathrm{com}$ munity gardens and a farm (Box Fig. 7.1). To get started, derelict land owned by the City was inventoried. Most of these properties were then converted to community gardens. Because the area has a history of soil contamination from a former metal smelter, soil testing is provided by the
City. Most gardening is done in raised beds, and the materials to construct the beds are provided by the City. Gardeners are also given topsoil amended with biosolids and yard waste compost for use within the beds. Cardboard diverted from the solid waste stream is placed between beds where it acts as a barrier to potentially contaminated soils. Wood waste is diverted from the composting site and used as mulch over the cardboard, which serves as a barrier to weeds and contaminants in the soil.
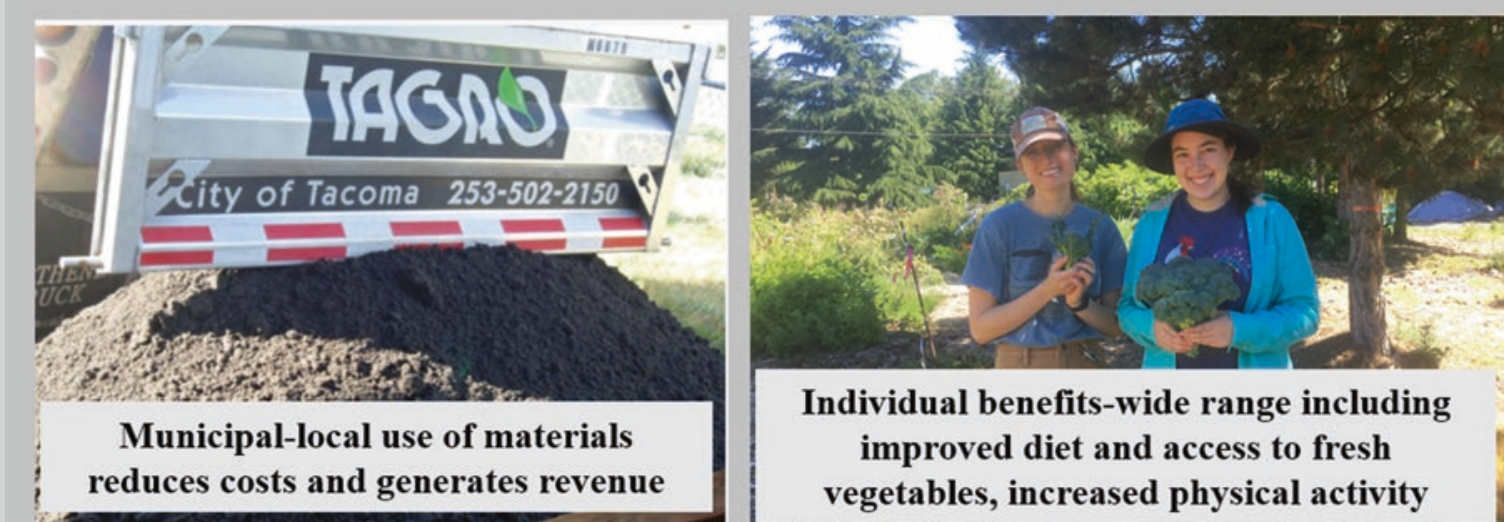

\section{Individual benefits-wide range including improved diet and access to fresh vegetables, increased physical activity}
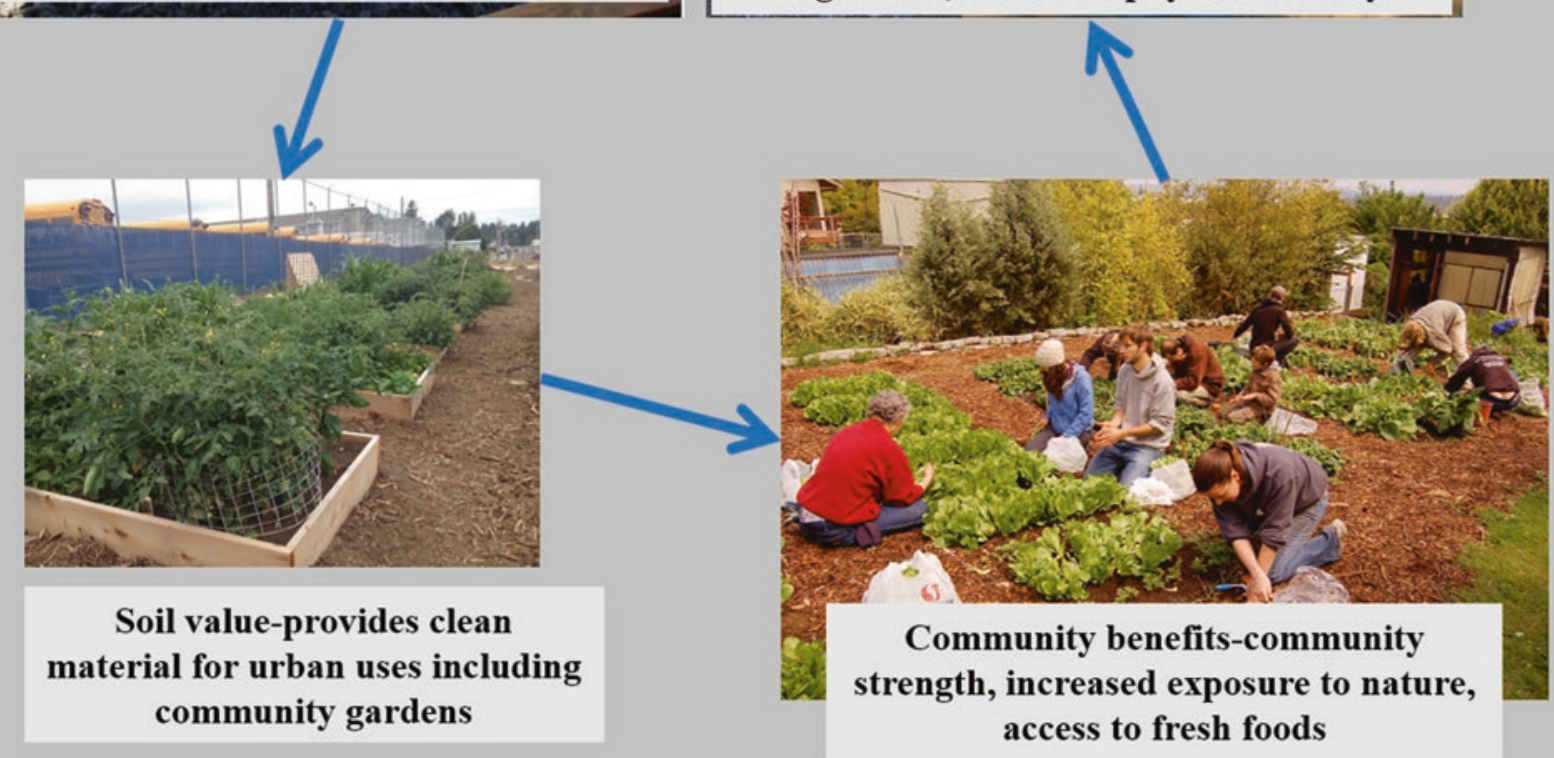

Box Fig. 7.1 An example of the many ways that municipal waste recycling can enhance urban soils and provide benefits

invasibility by nonnative species (Tilman 1999). Planning and managing for diverse plant communities is considered an important aspect of ecosystem stability in cities. For example, to provide resilience against potential insect pest outbreaks or extreme weather events, current recommendations for urban forest management specify that one genus should not make up more than $5 \%$ of the urban forest canopy
(Ball 2015). Yet soil disturbance from urbanization can have a homogenizing effect on planted species, especially when combined with cultural, policy, or economic pressures that may favor some species over others (Groffman et al. 2014). Relatively few tree species are well adapted to many of the soils associated with the conversion of agricultural or forested lands to urban uses. Historically, overreliance on a 
small number of species that are well adapted to such conditions, such as American elm (Ulmus americana), has contributed to outbreaks of pests, such as the Dutch elm disease fungus (Ophiostoma novo-ulmi), and reduced resilience. Thus, soil protection and management may have the potential to expand habitat for some species. The synergistic effects of altered climate, disturbance regimes, edaphic factors, and species introductions in urban landscapes may lead to unknown outcomes and diverse effects on ecological processes, thus requiring more research on these relationships in urban environments.

The connection between aboveground and belowground biodiversity is poorly understood in general and even more so under urban conditions. In heavily landscaped and managed urban settings, studies indicate that increasing the diversity of plants positively affects soil fauna diversity, leading to enhanced functions such as increased litter decomposition rates and soil organic matter buildup (Byrne 2007; Ossola et al. 2016). Additionally, adding trees to lawn areas, in parks, or in residential areas can lead to significant increases in soil organic matter in only a few decades (e.g., Setälä et al. 2016). Other factors such as the diversity of local habitat types and management inputs like irrigation can also be important drivers of soil biodiversity (Philpott et al. 2014; Smith et al. 2006), suggesting that managers and residents can play an important role in improving ecosystem services of urban soils (Box 7.2).

\section{Key Findings}

- Soil conditions in urban areas generally correspond to a range of anthropogenic effects, from relatively low influence (native forest or grassland soil) or indirect urban environmental effects (remnant forest stands) to those derived from human-created materials (landfills), sealed by impervious surfaces (asphalt), or altered by physical disturbances and management (residential yards).

- Despite the high levels of disturbance typically experienced by most urban soils, they, like their rural counterparts, have the potential to support plant, animal, and microbial organisms and mediate hydrological and biogeochemical cycles. The resultant communities of soil organisms are a unique combination of native species surviving or thriving in urban areas and species introduced from other regions or other continents.

- While urban soils can provide many types of ecosystem services (e.g., provisioning, regulating, supporting, and cultural), in many cases they may not be aligned with one

\section{Box 7.2 Plant Species Diversity and Urban Soil Ecosystem Services}

How does plant species diversity affect provisioning services provided by urban ecosystems? In forests adjacent to urban interstates in Louisville, KY, the characteristics of stands invaded by Lonicera maackii, a nonnative shrub (Box Fig. 7.2), and uninvaded stands (Box Fig. 7.3) varied, with invaded forests having half the plant species richness of uninvaded forests (Box Fig. 7.4). Soil carbon accumulation, an important ecosystem service, will likely be affected by these observed decreases in aboveground litter inputs associated with the lower plant diversity in invaded forests. To determine the impact of the decreased litter on soil C dynamics, soil carbon over a 30-year period was simulated using the CENTURY model. Results showed that soil $\mathrm{C}$ accumulation per year in uninvaded forests was almost four times greater than in invaded forests (Box Fig. 7.5).

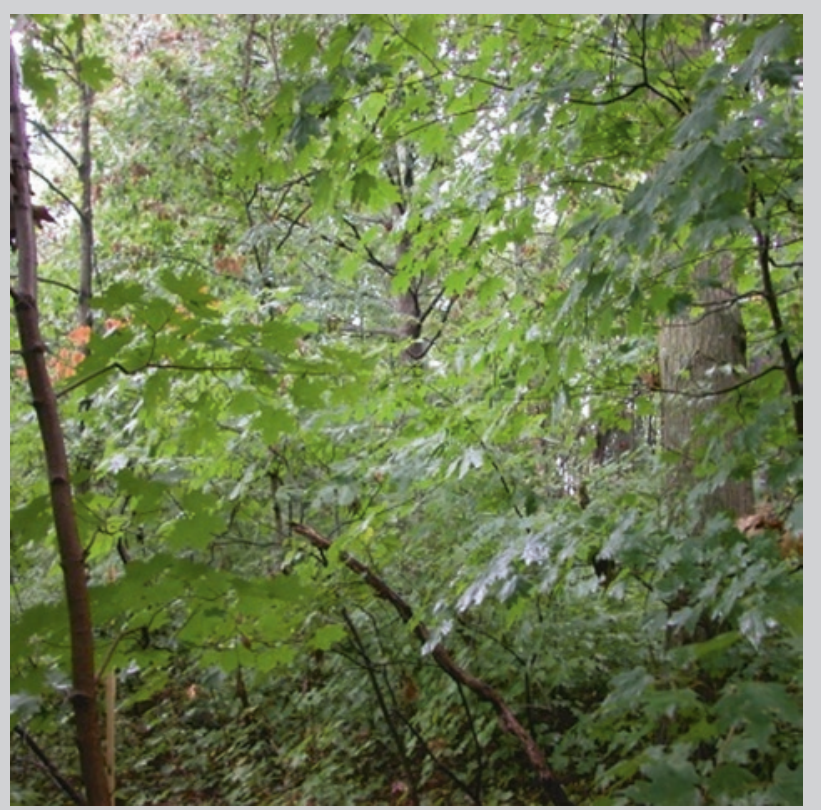

Box Fig. 7.2 Urban forest in Louisville, KY, that been invaded by the nonnative shrub, Lonicera maackii. (Photo credit: Tara Trammell, University of Delaware)

(continued) 


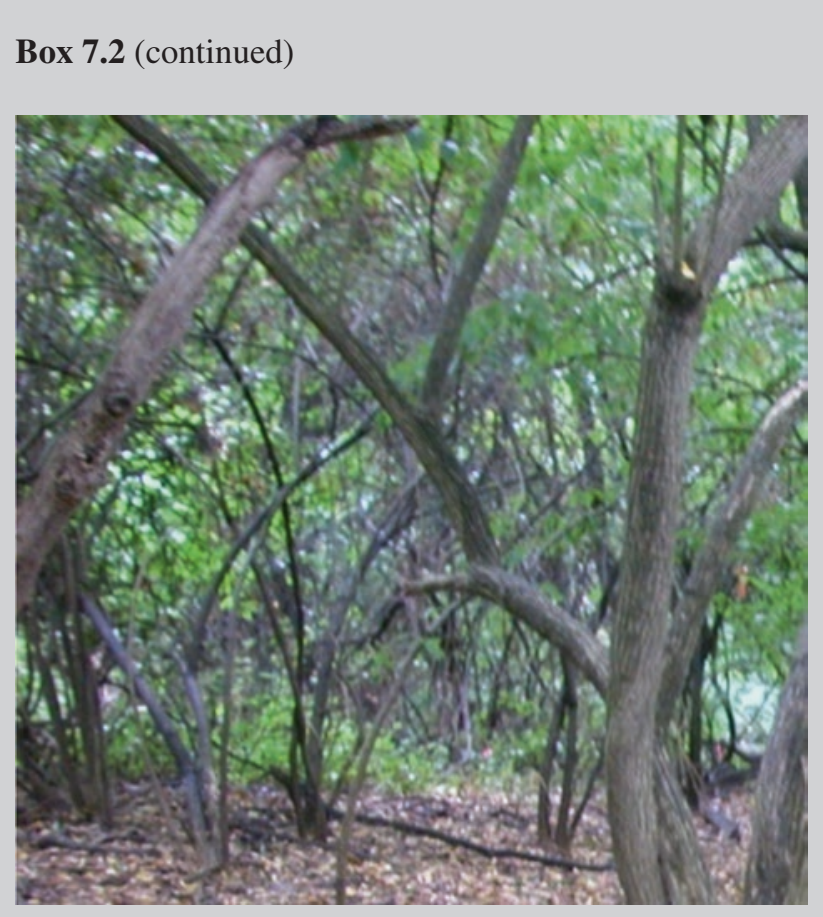

Box Fig. 7.3 Uninvaded urban forest in Louisville, KY. (Photo credit: Tara Trammell, University of Delaware)

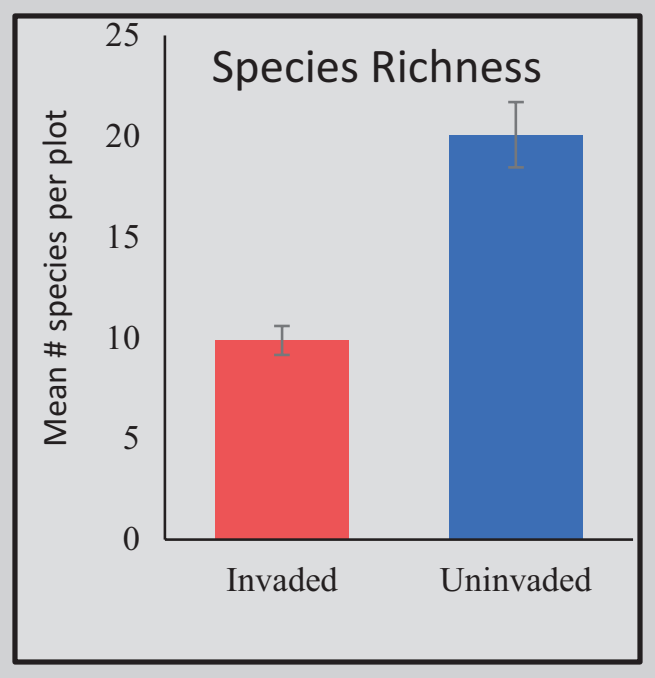

Box Fig. 7.4 Mean number of species $( \pm$ SE) per plot in invaded $(9 \pm 1)$ and uninvaded $(20 \pm 2)$ forests adjacent to urban interstates in Louisville, KY

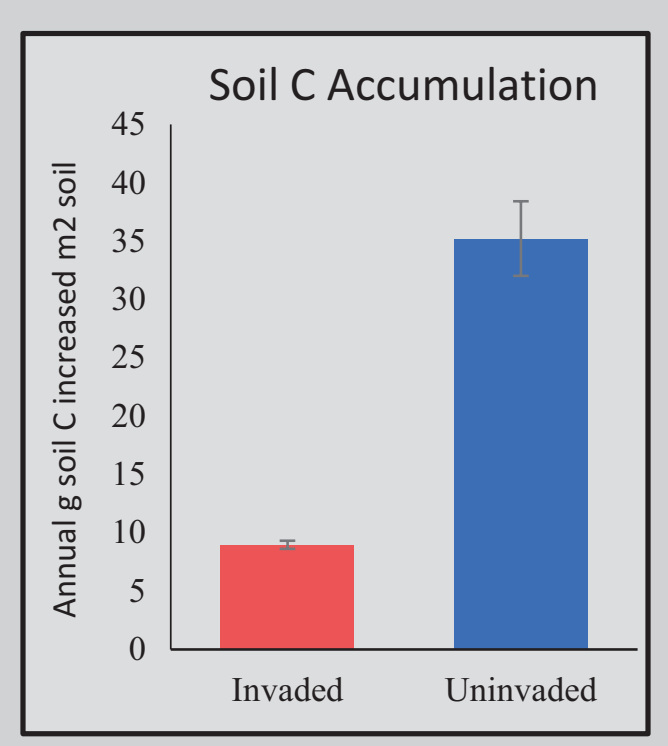

Box Fig. 7.5 Annual soil carbon accumulation ( $\mathrm{g} \mathrm{C} \mathrm{m}^{-2}$ soil) $($ mean \pm SE) in invaded $(9.0 \pm 0.35)$ and uninvaded $(35.2 \pm 3.20)$ forests adjacent to urban interstates in Louisville, KY

another, and in some cases they may even conflict. Therefore, managing soil for ecosystem services in urban areas requires an interdisciplinary approach.

- In the United States, the classification and survey of soils in urban landscapes has advanced tremendously in the last 20 years, with modern soil surveys being conducted in New York City, Chicago, Los Angeles, Detroit, and elsewhere. These surveys have provided detailed information on physical, chemical, and mineralogical properties of human-altered and human-transported soils, enabling more reliable interpretations for stormwater management, revegetation and restoration efforts, urban agriculture, and better resource inventory.

- Many urban environmental effects roughly correspond to changes that are occurring in the overall global climate; therefore, urban areas have been suggested as useful analogues to study the multifactorial effects of climate change on forest and grassland ecosystems.

\section{Key Information Needs}

- Novel conditions found in urban landscapes present a challenge for soil scientists who spatially describe urban soil characteristics (e.g., Box 7.3). More data needs to be 


\section{Box 7.3 Spatial Heterogeneity of Soil Lead}

The amount of lead $(\mathrm{Pb})$ in soil can be highly variable, and proximity to a source is often an important driver that can explain the spatial distribution of soil $\mathrm{Pb}$. Two important sources of lead include vehicular traffic (e.g., Bityukova et al. 2000) because $\mathrm{Pb}$ was used as a gasoline additive until 1986 (Mielke 1999) and interior and exterior leadbased paints, which were used until 1978 (Trippler et al. 1988). Elevated soil $\mathrm{Pb}$ levels have been observed next to buildings (Box Fig. 7.6) regardless of building material (wood and brick), and elevated soil lead is often associated with older housing (Schwarz et al. 2012).

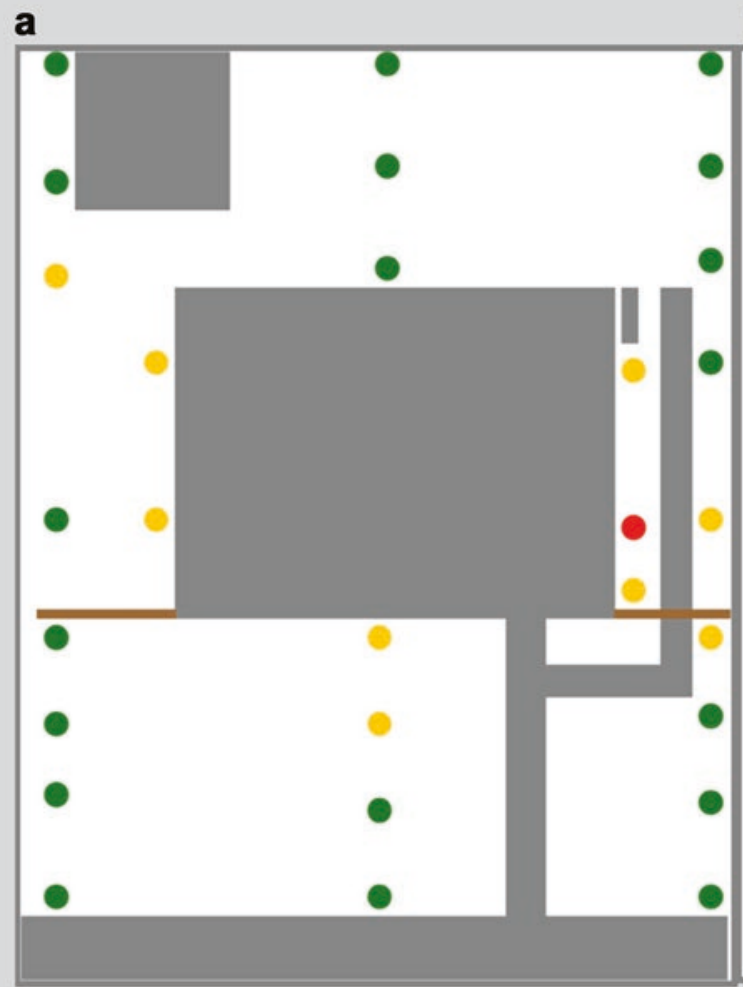

Box Fig. 7.6 Elevated soil lead $(\mathrm{Pb})$ levels are often found near buildings and are especially associated with older housing. (a) Gray areas represent the "footprint" for built structures or pavement, green circles represent soil $\mathrm{Pb}$ levels below $400 \mathrm{ppm}$, and yellow and red

b

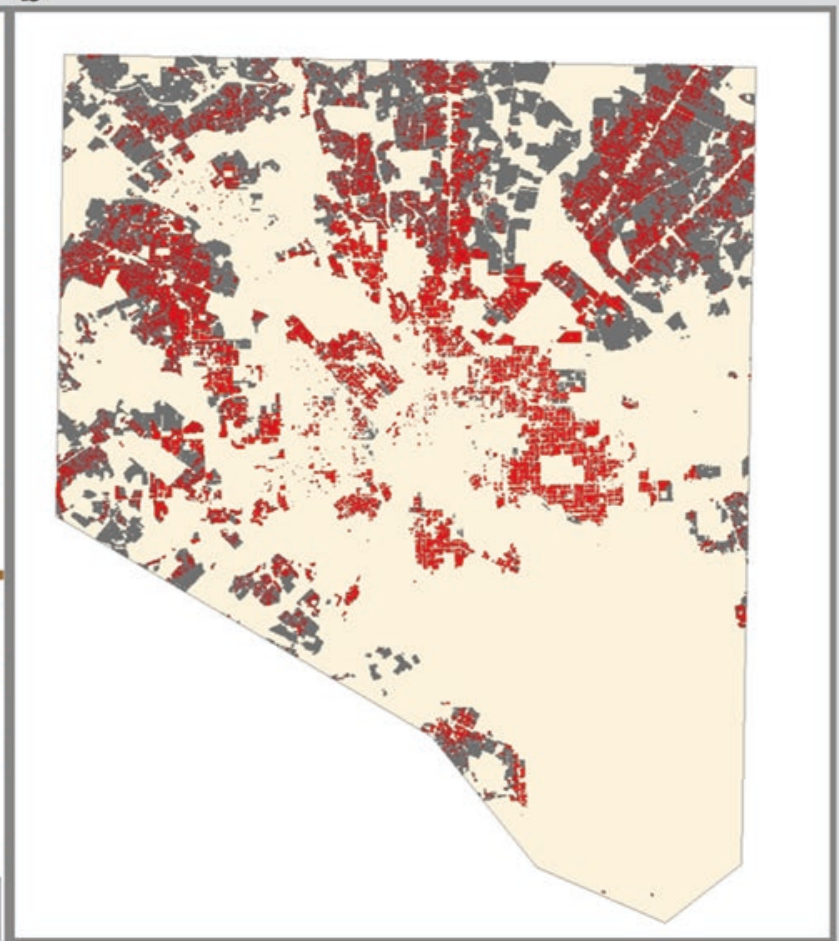

circles represent soil $\mathrm{Pb}$ levels above 400 ppm. (b) Parcel-level measurements can be used to create predictive models; areas in red are predicted to exceed $400 \mathrm{ppm}$ of soil $\mathrm{Pb}$, and areas in gray are predicted to fall below 400 ppm of soil Pb. (Source: Schwarz et al. 2013) obtained at multiple observational scales (site, city, metropolitan area) before this "new heterogeneity" is understood and effectively translated into current classification and mapping systems.

- Urban soils are often degraded with respect to the native soils that they have replaced, and likewise, they very often are covered with sealed surfaces such as asphalt and concrete pavements. More field studies are needed to quantify soil characteristics in urban landscapes as a whole and in particular beneath impervious surfaces.
- The existence of sealed surfaces in urban landscapes often necessitates the need to restore soil functions to a higher level (i.e., on a per unit area basis) than is typically found with native soils. For instance, developing a soil mix for a rain garden will require infiltration rates that are much higher than the rates of the previous native soil. Therefore, research and data are needed for the development of these "hyperfunctioning" soils.

- Studies and field observations are needed to quantify the benefits that are unique to urban soils. These may include, among others, the sustainable use of biosolids and the often unappreciated potential of using urban soils to facil- 
itate STEM (science, technology, engineering, and mathematics) education.

- The role of soil biota in urban soil formation, nutrient cycling, and other functions needs to be addressed more explicitly.

\section{Literature Cited}

Akbari $\mathrm{H}$ (2002) Shade trees reduce building energy use and $\mathrm{CO}_{2}$ emissions from power plants. Environ Pollut 116:S119-S126

Akbari H, Rose LS (2008) Urban surfaces and heat island mitigation potentials. J Human-Environ Syst 11:85-101

Arthur MA, Bray SR, Kuchle CR, McEwan RW (2012) The influence of the invasive shrub, Lonicera maackii, on leaf decomposition and microbial community dynamics. Plant Ecol 213:1571-1582

Ball J (2015) Using a 5 percent rule for tree selection. American Nurseryman. January 21, online

Bityukova L, Shogenova A, Birke M (2000) Urban geochemistry: a study of element distributions in the soils of Tallinn (Estonia). Environ Geochem Health 22:173-193

Bockheim JG (1974) Nature and properties of highly-disturbed urban soils, Philadelphia, Pennsylvania. Division S-5, Soil Genesis, Morphology and Classification, Annual Meeting of the Soil Science Society of America. Chicago, IL

Bolan N, Kunhikrishnan A, Thangarajan R et al (2014) Remediation of heavy metal(loid)s contaminated soils-to mobilize or to immobilize? J Hazard Mater 266:141-166

Burghardt W (2017) Main characteristics of urban soils. In: Levin MJ, KHJ K, Morel JL et al (eds) Soils within cities-global approaches to their sustainable management-composition, properties, and functions of soils of the urban environment. Schweizerbart Soil Sciences, Stuttgart, pp 19-26

Burrow C (2017) Influence of connectivity and topsoil management practices of a constructed technosol on pedofauna colonization: a field study. Appl Soil Ecol 123:416-419

Butler SM, Melillo JM, Johnson JE et al (2012) Soil warming alters nitrogen cycling in a New England forest: implications for ecosystem function and structure. Oecologia 168:819-828

Byrne LB (2007) Habitat structure: a fundamental concept and framework for urban soil ecology. Urban Ecosyst 10:255-274

Byrne LB, Bruns MA, Kim KC (2008) Ecosystem properties of urban land covers at the aboveground-belowground interface. Ecosystems 11:1065-1077

Calfapietra C, Peñuelas J, Niinemets U (2015) Urban plant physiology: adaptation-mitigation strategies under permanent stress. Trends Plant Sci 20:72-75

Capra GF, Ganga A, Grilli E et al (2015) A review on anthropogenic soils from a worldwide perspective. J Soils Sediments 15:1602-1618

Carr R, Zhang C, Moles N, Harder M (2007) Identification and mapping of heavy metal pollution in soils of a sports ground in Galway City, Ireland, using a portable XRF analyzer and GIS. Environ Geochem Health 30:42-52

Carreiro MM, Sinsabaugh RL, Repert DA, Parkhurst DF (2000) Microbial enzyme shifts explain litter decay responses to simulated nitrogen deposition. Ecology 81:2359-2365

Carreiro MM, Pouyat RV, Tripler C, Zhu W (2009) Carbon and nitrogen cycling in soils of remnant forests along urban-rural gradients: case studies in the New York metropolitan area and Louisville, Kentucky. In: McDonnell MJ, Hahs A, Breuste J (eds) Ecology of cities and towns: a comparative approach. Cambridge University Press, Cambridge, pp 308-328
Chen Y, Day SD, Wick AF (2013) Changes in soil carbon pools and microbial biomass from urban land development and subsequent post-development soil rehabilitation. Soil Biol Biochem 66:38-44

Chen Y, Day SD, Wick AF, McGuire KJ (2014) Influence of urban land development and subsequent soil rehabilitation on soil aggregates, carbon, and hydraulic conductivity. Sci Total Environ 494:329-336

Chen Y, Wang X, Jiang B, Yang N, Li L (2016) Pavement induced soil warming accelerates leaf budburst of ash trees. Urban For Urban Greening 16:36-42

Craine JM, Fierer N, McLauchlan KK (2010) Widespread coupling between the rate and temperature sensitivity of organic matter decay. Nat Geosci 3:854-857

Craul PJ (1992) Urban soil in landscape design. Wiley, New York

Craul PJ, Klein CJ (1980) Characterization of streetside soils of Syracuse, New York. Metria 3:88-101

Doolittle J, Hernandez L, Galbraith J (1997) Using ground penetrating radar to characterize a landfill site. Soil Surv Horizons 38:60-67

Drouin M, Bradley R, Lapointe L (2016) Linkage between exotic earthworms, understory vegetation and soil properties in sugar maple forests. For Ecol Manag 364:113-121

Effland WR, Pouyat RV (1997) The genesis, classification, and mapping of soils in urban areas. Urban Ecosyst 1:217-228

Ehrenfeld JG (2010) Ecosystem consequences of biological invasions. Annu Rev Ecol Evol Syst 41:59-80

Emilsson T, Rolf K (2005) Comparison of establishment methods for extensive green roofs in southern Sweden. Urban For Urban Greening 3:103-111

Evans CV, Fanning DS, Short JR (2000) Human-influenced soils. Agron Monogr 39:33-67

Farfel MR, Orlova AO, Chaney RL et al (2005) Biosolids compost amendment for reducing soil lead hazards: a pilot study of Orgro ${ }^{\circledR}$ amendment and grass seeding in urban yards. Sci Total Environ 340:81-95

Findlay S, Carreiro M, Krischik V, Jones C (1996) Effects of damage to living plants on leaf litter quality. Ecol Appl 6:269-275

Garthwaite RL, Lawson R, Sassaman C (1995) Population genetics of Armadillidium vulgare in Europe and North America. Crustacean Issues 9:145-199

Grabosky J, Bassuk N, Marranca BZ (2002) Preliminary findings from measuring street tree shoot growth in two skeletal soil installations compared to tree lawn plantings. J Arboric 28:106-108

Gregg JW, Jones CG, Dawson TE (2003) Urbanization effects on tree growth in the vicinity of New York City. Nature 424:183-187

Groffman PM, Williams CO, Pouyat RV et al (2009) Nitrate leaching and nitrous oxide flux in urban forests and grasslands. J Environ Qual 38:1848-1860

Groffman PM, Cavender-Bares J, Bettez ND et al (2014) Ecological homogenization of urban USA. Front Ecol Environ 12:74-81

Heidt V, Neef M (2008) Benefits of urban green space for improving urban climate. In: Carreiro M, Song Y, Wu J (eds) Ecology, planning, and management of urban forests. Springer, New York

Herrmann DL, Shuster WD, Garmestani AS (2017) Vacant urban lot soils and their potential to support ecosystem services. Plant Soil 413(1-2):45-57

Hobbs RJ, Arico S, Aronson J et al (2006) Novel ecosystems: theoretical and management aspects of the new ecological world order. Glob Ecol Biogeogr 15:1-7

Hornung E, Szlavecz K (2003) Establishment of a Mediterranean isopod (Chaetophiloscia sicula Verhoeff, 1908) in a North American temperate forest. Crustaceana Monogr 2:181-189

Howard JL, Orlicki KM (2015) Effects of anthropogenic particles on the chemical and geophysical properties of urban soils, Detroit. Mich Soil Sci 180:154-166

Huot H, Simonnot M-A, Morel JL (2015) Pedogenetic trends in soils formed in technogenic parent materials. Soil Sci 180:182-192 
Jo I, Fridley JD, Frank DA (2015) Linking above- and belowground resource use strategies for native and invasive species of temperate deciduous forests. Biol Invasions 17:1545-1554

Jochner S, Menzel A (2015) Urban phenological studies—past, present, future. Environ Pollut 203:250-261

Kadas G (2006) Rare invertebrates colonizing green roofs in London. Urban Habitats 4:66-86

Kaushal SS, Belt KT (2012) The urban watershed continuum: evolving spatial and temporal dimensions. Urban Ecosyst 15(2):409-435

Korsós Z, Hornung E, Kontschán J, Szlavecz K (2002) Isopoda and Diplopoda of urban habitats: new data to the fauna of Budapest. Annales Historico Naturales Musei Nationalis Hungarici 94:193-208

Kourtev PS, Ehrenfeld JG, Häggblom M (2003) Experimental analysis of the effect of exotic and native plant species on the structure and function of soil microbial communities. Soil Biol Biochem 35(7):895-905

Kumpiene J, Lagerkvist A, Maurice C (2008) Stabilization of As, Cr, $\mathrm{Cu}, \mathrm{Pb}$ and $\mathrm{Zn}$ in soil using amendments-a review. Waste Manag 28:215-225

Law NL, Band LE, Grove JM (2004) Nutrient input from residential lawn care practices. J Environ Manag 47:737-755

Lehmann A, Stahr K (2007) Nature and significance of anthropogenic urban soils. J Soils Sediments 7:247-260

Liao C, Peng R, Luo Y et al (2008) Altered ecosystem carbon and nitrogen cycles by plant invasion: a meta-analysis. New Phytol 177:706-714

Lindroth CH (1957) The faunal connections between Europe and North America. Wiley, New York. 344 p

Lovett G, Tranor M, Pouyat RV et al (2000) N deposition along an urban-rural gradient in the New York City metropolitan area. Environ Sci Technol 34:4294-4300

MacIvor JS, Lundholm J (2011) Insect species composition and diversity on intensive green roofs and adjacent level-ground habitats. Urban Ecosyst 14:225-241

Madre F, Vergnes A, Machon N, Clergeau P (2013) A comparison of 3 types of green roof as habitats for arthropods. Ecol Eng 57:109-117

McGuire KL, Payne SG, Palmer MI et al (2013) Digging the New York City skyline: soil fungal communities in green roofs and city parks. PLoS One 8(3):e58020

McKinney ML (2006) Urbanization as a major cause of biotic homogenization. Biol Conserv 127:247-260

Mielke HW (1999) Lead in the inner cities. Am Sci 87:62-73

Milesi C, Running SW, Elvidge CD et al (2005) Mapping and modeling the biogeochemical cycling of turf grasses in the United States. Environ Manag 36:426-438

Molineux CJ, Fentiman CH, Gange AC (2009) Characterizing alternative recycled waste materials for use as green roof growing media in the U.K. Ecol Eng 35:1507-1513

Morel JL, Chenu C, Lorenz K (2015) Ecosystem services provided by soils of urban, industrial, traffic, mining, and military areas (SUITMAs). J Soils Sediments 15:1659-1666

Morel JL, Burghardt W, Kim K-HJ (2017) The challenges for soils in the urban environment. In: Levin MJ, Kim K-HJ, Morel JL et al (eds) Soils within cities-global approaches to their sustainable management-composition, properties, and functions of soils of the urban environment. Schweizerbart Soil Sciences, Stuttgart, pp 1-6

Morton TG, Gold AJ, Sullivan WM (1988) Influence of overwatering and fertilization on nitrogen losses from home lawns. J Environ Qual 17:124-130

Niyogi D, Pyle P, Lei M et al (2011) Urban modification of thunderstorms: an observational storm climatology and model case study for the Indianapolis urban region. J Appl Meteorol Climatol 50:1-13

Oke TR (1990) The micrometeorology of the urban forest. Q J R Meteorol Soc 324:335-349
Osmond DL, Hardy DH (2004) Characterization of turf practices in five North Carolina communities. J Environ Qual 33:565-575

Ossola A, Hahs AK, Nash MA, Livesley SJ (2016) Habitat complexity enhances comminution and decomposition processes in urban ecosystems. Ecosystems 19:927-941

Pardo LH, Fenn ME, Goodale CL et al (2011) Effects of nitrogen deposition and empirical nitrogen critical loads for ecoregions of the United States. Ecol Appl 21:3049-3082

Pavao-Zuckerman MA (2012) Urbanization, soils and ecosystem services. In: Wall DH, Bardgett RD, Behan-Pelletier V, Herrick JE, Jones TH, Ritz K, Six J, Strong DR, van der Putten WH (eds) Soil ecology and ecosystem services. Oxford University Press, Oxford, pp 270-281

Philpott SM, Cotton J, Bichier P et al (2014) Local and landscape drivers of arthropod abundance, richness and trophic composition in urban habitats. Urban Ecosyst 17:513-532

Piotrowska-Dlugosz A, Charzynski P (2015) The impact of the soil sealing degree on microbial biomass, enzymatic activity, and physiochemical properties in the Ekranic Technosols of Torun (Poland). J Soils Sediments 15:47-59

Poland TM, McCullough DG (2006) Emerald ash borer: invasion of the urban forest and the threat to North America's ash resource. J For 104(3):118-124

Pouyat RV, Carreiro MM (2003) Contrasting controls on decomposition of oak leaf litter along an urban-rural land use gradient. Oecologia 135:288-298

Pouyat RV, Groffman PM, Yesilonis I, Hernandez L (2002) Soil carbon pools and fluxes in urban ecosystems. Environ Pollut 116:107-118

Pouyat RV, Yesilonis I, Russell-Anelli J, Neerchal NK (2007) Soil chemical and physical properties that differentiate urban land-use and cover. Soil Sci Soc Am J 71(3):1010-1019

Pouyat RV, Carreiro MM, Groffman PM, Zuckerman M (2009) Investigative approaches to urban biogeochemical cycles: New York metropolitan area and Baltimore as case studies. In: McDonnell MJ, Hahs A, Breuste J (eds) Ecology of cities and towns: a comparative approach. Cambridge University Press, Cambridge/Oxford, pp 329-354

Pouyat RV, Szlavecz K, Yesilonis I et al (2010) Chemical, physical, and biological characteristics of urban soils. In: Aitkenhead-Peterson J (ed) Urban ecosystem ecology. Agronomy Society of America; Crop Science Society of America; Soil Science Society of America, Madison, pp 119-152

Pouyat RV, Setälä H, Szlavecz K et al (2017) Introducing GLUSEEN: a new open access and experimental network in urban soil ecology. J Urban Ecol 3(1):jux002

Raciti SM, Hutyra LR, Finzi AC (2012) Depleted soil carbon and nitrogen pools beneath impervious surfaces. Environ Pollut 164:248-251

Rao P, Hutyra LR, Raciti SM, Templer PH (2014) Atmospheric nitrogen inputs and losses along an urbanization gradient from Boston to Harvard Forest, MA. Biogeochemistry 121:229-245

Rossiter DG (2007) Classification of urban and industrial soils in the World Reference Base for Soil Resources. J Soils Sediments 7:96-100

Roy-Poirier A, Champagne P, Filion Y (2010) Review of bioretention system research and design: past, present, and future. J Environ Eng 136:878-889

Royte E (2009) The street farmer. The New York Times Sunday Magazine. July 1: MM22

Ryan JA, Zhang P, Chou J, Sayers DE (2001) Formation of chloropyromorphite in a lead-contaminated soil amended with hydroxyapatite. Environ Sci Technol 35:3798-3803

Sackett TE, Smith SM, Basiliko N (2013) Indirect and direct effects of exotic earthworms on soil nutrient and carbon pools in North American temperate forests. Soil Biol Biogeochem 57:459-467

Scalenghe R, Marsan FA (2009) The anthropogenic sealing of soils in urban areas. Landsc Urban Plan 90:1-10 
Scharenbroch BC, Johnston DP (2011) A microcosm study of the common night crawler earthworm (Lumbricus terrestris) and physical, chemical and biological properties of a designed urban soil. Urban Ecosyst 14:119-134

Scharenbroch B, Day S, Trammell T, Pouyat RV (2018) Chapter 6: Urban soil carbon storage. In: Lal R, Stewart BA (eds) Urban soils. Advances in soil sciences, Boca Raton, CRC Press

Schrader S, Böning M (2006) Soil formation on green roofs and its contribution to urban biodiversity with emphasis on collembolans. Pedobiologia 50:347-356

Schwartz SS, Smith B (2016) Restoring hydrologic function in urban landscapes with suburban subsoiling. J Hydrol 543:770-781

Schwarz K, Pickett STA, Lathrop RG et al (2012) The effects of the urban built environment on the spatial distribution of lead in residential soils. Environ Pollut 163:32-39

Schwarz K, Weathers KC, Pickett STA et al (2013) A comparison of three empirically-based, spatially explicit predictive models of residential soil $\mathrm{Pb}$ concentrations in Baltimore, Maryland USA: understanding the variability within cities. Environ Geochem Health 35:495-510

Schwarz K, Pouyat RV, Yesilonis ID (2016) Legacies of lead in charm city's soil: lessons from the Baltimore Ecosystem Study. Int J Environ Res Public Health 13:209

Seidl M, Gromaire MC, Saad M, De Gouvello B (2013) Effect of substrate depth and rain-event history on the pollutant abatement of green roofs. Environ Pollut 183:195-203

Setälä H, Birkhofer K, Brady M et al (2014) Urban and agricultural soils: conflicts and trade-offs in the optimization of ecosystem services. Urban Ecosyst 17:239-253

Setälä HK, Francini G, Allen JA et al (2016) Vegetation type and age drive changes in soil properties, nitrogen, and carbon sequestration in urban parks under cold climate. Front Ecol Evol 4:93

Shaw RK, Isleib JT (2017) The case of the New York City Soil Survey Program, United States. In: Levin MJ, K-HJ K, Morel JL et al (eds) Soils within cities: global approaches to their sustainable management. Schweizerbart, Catena Soil Sciences, Stuttgart, pp 107-113

Shem W, Shepherd M (2009) On the impact of urbanization on summertime thunderstorms in Atlanta: two numerical model case studies. Atmos Res 92:172-189

Shepherd JM, Burian SJ (2003) Detection of urban-induced rainfall anomalies in a major coastal city. Earth Interact 7:1-14

Short JR, Fanning DS, Foss JE, Patterson JC (1986) Soils of the mall in Washington, DC: I Statistical summary of properties. Soil Sci Soc Am J 50:699-705

Shuster WD, Dadio S (2017) Chapter 12: An applied hydropedological perspective on the rendering of ecosystem services from urban soils. In: Lal R, Stewart BA (eds) Urban soils. Advances in soil science. CRC Press, Boca Raton

Shuster WD, Dadio S, Drohanc P et al (2014) Residential demolition and its impact on vacant lot hydrology: implications for the management of stormwater and sewer system overflows. Landsc Urban Plan 125:48-56

Sloan JJ, Ampim PAY, Basta NT, Scott R (2012) Addressing the need for soil blends and amendments for the highly modified urban landscape. Soil Sci Soc Am J 76:1133

Smetak KM, Johnson-Maynard JL, Lloyd JE (2007) Earthworm population density and diversity in different-aged urban systems. Appl Soil Ecol 37:161-168

Smith RM, Warren PH, Thompson K, Gaston KJ (2006) Urban domestic gardens (VI): environmental correlates of invertebrate species richness. Biodivers Conserv 15:2415-2438

Soil Survey Staff (2014) Keys to soil taxonomy, 12th edn. U.S. Department of Agriculture, Natural Resources Conservation Service, Washington, DC
Song Y, Liu H, Wang X et al (2016) Numerical simulation of the impact of urban non-uniformity on precipitation. Adv Atmos Sci 33:783-793

Spoor G, Tijink F, Weisskopf P (2003) Subsoil compaction: risk, avoidance, identification and alleviation. Soil Tillage Res 73:175-182

Szlavecz K, Placella SA, Pouyat RV et al (2006) Invasive earthworm species and nitrogen cycling in remnant forest patches. Appl Soil Ecol 32:54-63

Szlavecz K, McCormick M, Xia L et al (2011) Ecosystem effects of nonnative earthworms in mid-Atlantic deciduous forests. Biol Invasions 15:1165-1182

Szlavecz K, Yesilonis I, Pouyat R (2018) Soil as foundation for urban biodiversity. In: Ossola A, Niemelä J (eds) Urban biodiversity: from research to practice. Taylor and Francis, London, pp 18-36

Taha H (1997) Urban climates and heat islands: albedo, evapotranspiration, and anthropogenic heat. Energy Buildings 25:99-103

Tilman D (1999) The ecological consequences of changes in biodiversity: a search for general principles. Ecology 80:1455-1474

Trammell TLE, Ralston HA, Scroggins SA, Carreiro MM (2012) Foliar production and decomposition rates in urban forests invaded by the exotic invasive shrub, Lonicera maackii. Biol Invasions 14:529-545

Trammell TLE, Pataki DE, Cavender-Bares J et al (2016) Plant nitrogen concentration and isotopic composition in residential lawns across seven US cities. Oecologia 181:271-285

Trippler DJ, Schmitt MDC, Lund GV (1988) Soil lead in Minnesota. In: Davies BE, Wixson BG (eds) Lead in soil: issues and guidelines. Environmental geochemistry and health. Science Reviews, Northwood

U.S. Census Bureau (2010) Annual estimates of the resident population: April 1, 2010 to July, 2013. http://www.census.gov/population/ metro/data/index.html. Accessed 24 Oct 2014

United Nations (2015) World population prospects: the 2015 revision, key findings and advance tables. Working Paper ESA/P/WP.241. United Nations, Department of Economic and Social Affairs, Population Division, New York

USDA Natural Resources Conservation Service (USDA NRCS) (2001) Summary report: 1997 National Resources Inventory (revised December 2000). U.S. Department of Agriculture, Natural Resources Conservation Service/Iowa State University, Statistical Laboratory, Washington, DC/Ames. 89 p

Washbourne CL, Lopez-Capel E, Renforth P, Ascough PL (2015) Rapid removal of atmospheric $\mathrm{CO}_{2}$ by urban soils. Environ Sci Technol 49:5434-5440

Wessolek G (2008) Sealing of soils. In: Marzluff J, Shulenberger E, Endlicher W et al (eds) Urban ecology, an international perspective on the interaction between humans and nature. Springer, New York, pp 161-179

Wolf JM, Gibbs JP (2004) Silphids in urban forests: diversity and function. Urban Ecosyst 7:371-384

Xu S, Xu W, Chen W et al (2016) Leaf phenological characters of main tree species in urban forest of Shenyang. PLoS One 9:e99277

Yesilonis ID, Pouyat RV (2012) Carbon stocks in urban forest remnants: Atlanta and Baltimore as case studies. In: Lal R, Augustin B (eds) Carbon sequestration in urban ecosystems. Springer, Dordrecht, pp 103-120

Youngsteadt E, Henderson RC, Savage AM et al (2015) Habitat and species identity, not diversity, predict the extent of refuse consumption by urban arthropods. Glob Chang Biol 21:1103-1115

Zemlyanitskiy LT (1963) Characteristics of the soils in the cities. Soviet Soil Sci 5:468-475

Zhao L, Lee X, Smith RB, Oleson K (2014) Strong contributions of local background climate to urban heat islands. Nature 511:216-221 
Open Access This chapter is licensed under the terms of the Creative Commons Attribution 4.0 International License (http://creativecommons. org/licenses/by/4.0/), which permits use, sharing, adaptation, distribution and reproduction in any medium or format, as long as you give appropriate credit to the original author(s) and the source, provide a link to the Creative Commons license and indicate if changes were made.

The images or other third party material in this chapter are included in the chapter's Creative Commons license, unless indicated otherwise in a credit line to the material. If material is not included in the chapter's Creative Commons license and your intended use is not permitted by statutory regulation or exceeds the permitted use, you will need to obtain permission directly from the copyright holder. 